\title{
Den kapitalistiska staten och möjligheten till socialism
}

\author{
Erik Olin Wright
}

SAMMANDRAG: Inom ramen för samarbetsprojektet The Real Utopias Project har Erik Olin Wright sedan 199I lett utforskandet av olika modeller för radikal social förändring genom en mängd antologier och monografier, bland annat i Envisioning real utopias (från 20Io). I denna artikel undersöker Wright hur Göran Therborns bok Vad gör den härskande klassen när den härskar? från 1978 (på svenska 1980) kan användas för att utveckla ett möjligt socialistiskt alternativ till kapitalismen som är relevant för den antikapitalistiska kampen i dag. Therborns bok handlar om hur vi ska förstå staten och dess roll för att reproducera rådande klassförhållanden. För den arbetarrörelse som under 1900talet - genom demokratiska val eller revolution - försökte omvandla samhället genom ett erövrande av statsmakten var detta ett centralt problem. Wright visar hur Therborns analys fortfarande har relevans för de som, i ljuset av "realsocialismens" misslyckanden och övergrepp och kapitalismens globala expansion med skenande miljöförstöring och ojämlikhet i släptåg, försöker formulera ett begrepp om en sant demokratisk socialism och utveckla möjliga strategier för att utmana och överskrida det förhärskande ekonomiska systemet.

NYCKELORD: staten; statsapparater; makt; klassförhållanden; kapitalism; etatism; antikapitalism; socialism; ekonomisk demokrati; Göran Therborn.

PUBLICERINGSHISTORIK: Översättning av kapitlet "The capitalist state and the possibility of socialism" från Gunnar Olofsson \& Sven Hort (red.), Class, sex and revolutions. Göran Therborn - a critical appraisal, Arkiv förlag 2016.

ERIK OLIN WRIGHT är professor i sociologi vid University of Wisconsin-Madison. E-POSTADRESS: eowright@wisc.edu

FÖRSLAG PÅ KÄLLANGIVELSE:

Wright, Erik Olin (20I7) "Den kapitalistiska staten och möjligheten till socialism", i Arkiv. Tidskrift för sambällsanalys, nr 8, s. 47-76. DOI: https://doi.org/10.13068/2000-6217.8.2

(C) original: Erik Olin Wright/Arkiv förlag 2016

(C) svensk version: Erik Olin Wright/Arkiv förlag \& tidskrift 2017

(publicerad 23 maj 20I7)

Artikeln distribueras enligt en upphovsrättslicens från Creative Commons:

Erkännande-Ickekommersiell-IngaBearbetningar 3.0 Unported, som medger fri ickekommersiell användning och spridning i oförändrat skick så länge källan anges. 
Arkiv. Tidskrift för samhällsanalys är en sakkunniggranskad vetenskaplig tidskrift för samhällsvetenskap och historia. Samtliga artiklar publiceras fritt tillgängliga på:

$$
\text { www.tidskriftenarkiv.se }
$$

Beständig länk, DOI: https://doi.org/IO.13068/2000-62I7

Den här artikeln finns tillgänglig i följande format:

PDF \& HTML: via beständig länk, DOI: https://doi.org/IO.I3068/2000-6217.8.2 EPUB: ingår i e-boksutgåva av numret, ISBN: 978 9I 79242909

TRYCK: ingår i bokutgåva av numret, ISBN: 978 9I 7924 29I 6

Grafisk utformning och sidnumrering är identisk i pdf och tryck.

Samtliga artiklar i nr 8 (20I7) nås via beständig länk, DOI: https://doi.org/IO.I3068/2000-6217.8

Arkiv. Tidskrift för samhällsanalys ISSN: 2000-62I7 (för elektronisk resurs) ISSN: 2000-6225 (för tryckta nummer)

ges ut av

Stiftelsen Arkiv för främjande och spridning av samhällsvetenskaplig och historisk forskning

genom

Arkiv förlag \& tidskrift

Box 1559 SE-22I OI Lund

BESÖK: L Gråbrödersg 3 c, ipg TEL: 046-I3 3920

ARKIV FÖRLAG: arkiv@arkiv.nu·www.arkiv.nu

TIDSKRIFTEN ARKIV: red@tidskriftenarkiv.se.www.tidskriftenarkiv.se

ANSVARIg UTGIVARE \& CHEFREDAKTÖR: Sven Hort

Administrativ Redaktör: David Lindberg Redaktörer: Paavo Bergman, Per Dannefjord, Lisa Kings,

Zhanna Kravchenko, Anna-Maria Sarstrand Marekovic 


\section{Den kapitalistiska staten och möjligheten till socialism}

\section{ERIK OLIN WRIGHT}

Den mest grundläggande utmaningen som marxistisk teori står inför i dag är att utveckla ett socialistiskt alternativ till kapitalismen som är strategiskt relevant för den antikapitalistiska kampen under 2000-talet. Problemet är här både svårigheten att formulera ett sammanhängande och övertygande begrepp om socialism i sig efter 1900-talets historiska erfarenheter och svårigheten att utveckla en rimlig strategi för utmaning av kapitalismen som kan bidra till att förverkliga socialismen, hur den nu än definieras. Hur vi teoretiskt förstår staten har relevans för båda dessa frågor: staten är en av de centrala strukturer som bidrar till kapitalismens reproduktion och hindrar kampen för omvandling, och staten måste spela en central roll i en framgångsrik konstruktion av ett socialistiskt alternativ.

Jag kommer här att utforska några av de sätt på vilka Göran Therborn med sin bok Vad gör den härskande klassen när den härskar? kan vara till hjälp i mötet med denna utmaning. Boken kom ut 1978 (på svenska 1980), på höjden av den våg av innovativt teoretiskt arbete inom marxismen som inleddes i mitten av 1960-talet. Den utgör det mest systematiska försöket att ge analytisk stringens åt idén att i det kapitalistiska samhället är staten en kapitalistisk stat snarare än bara en stat $i$ det kapitalistiska sambället.

Artikeln är en översättning av "The capitalist state and the possibility of socialism”, från Gunnar Olofsson \& Sven Hort (red.), Class, sex and revolutions. Göran Therborn - a critical appraisal, Arkiv förlag 2016. 
Även om denna idé har en lång stamtavla i den marxistiska traditionen och fick förnyad uppmärksamhet några år tidigare i en debatt i New Left Review mellan Ralph Miliband och Nicos Poulantzas (Poulantzas 1969; Miliband 1970, 1973; Poulantzas 1976), hade ingen djupare utforskat de teoretiska implikationerna av detta påstående eller försökt utveckla en begreppskarta över den kapitalistiska statens klasskaraktär.

Boken skrevs i en tid av betydande optimism och självförtroende hos vänstern. De utvecklade kapitalistiska ekonomierna satt fast i stagflation och tycktes oförmögna att övervinna sina interna kriser. Det radikala uppsvinget under 1960-talet och början av 1970-talet hade stimulerat nya tankar och teoretisk kraft, särskilt inom den marxistiska traditionen. Och trots det förfärliga krossandet av Allendes styre i Chile tycktes möjligheterna för stora framsteg för vänstern i allmänna val vara reella. I sin diskussion av idén om en härskande klass kunde Therborn fortfarande utforska "hur [den] kan störtas" (s. I28, ensamma sidhänvisningar hänvisar alla till Therborn 1980 [1978]). Resultatet blev att Therborn i slutet av boken, efter att ha skrivit om både möjligheterna och motsättningarna i arbetarklasspartiernas olika strategier i Europa, kunde uttrycka sig så här: "Dessa och många andra motsägelser och problem återstår fortfarande att övervinna - och de kommer att övervinnas på det ena eller andra sättet. För att på rätt sätt kunna ta itu med dem är det emellertid bäst att förbereda sig på dem i förväg” (s. 282).

I 2000-talets andra decennium är det svårt att uppbåda det slaget av övertygelse om att de motsägelser som de antikapitalistiska strategierna står inför "kommer att övervinnas på det ena eller andra sättet". Jag kommer i det följande att argumentera för att det kan vara möjligt att hantera de djupa motsägelser som varje strategi för överskridande av kapitalismen ställs inför, men för det krävs, än en gång, ett nytt tänkande om statens förhållande till problemet. Jag kommer först att granska de centrala argumenten i Vad gör den härskande klassen när den härskar? och sedan visa hur Therborns ramverk, med viss modifiering, kan bidra till att öppna en dagordning för hantering av det strategiska problemet att utmana kapitalismen. 


\section{Bokens centrala argument}

\section{Statsmaktens och statsapparaternas klasskaraktär}

I titeln på Therborns bok ställs frågan "Vad gör den härskande klassen när den härskar?" Svaret på den frågan är följande:

När vi säger att en klass innehar statsmakten menar vi att det som görs genom staten positivt inverkar på (re)produktionen av det produktionssätt, av vilket ifrågavarande klass är den ledande bäraren (s. I39).

Vad gör då den härskande klassen när den härskar? Jo, i grund och botten (re-) producerar den sitt herraväldes ekonomiska, politiska och ideologiska relationer. Detta välde utövas genom statsmakten, det vill säga genom statens ingripanden och lösningar och deras effekter på den härskande klassens ställning inom produktionens, statsapparatens och det ideologiska systemets relationer (s. I56-I57).

Makt definieras i denna formulering som förmågan att framkalla effekter i världen. ${ }^{I}$ Statens makt är alltså statens förmåga att skapa effekter genom sina handlingar, där staten själv definieras som "en särskild institution, som i sig koncentrerar detta samhälles högsta regelskapande, regeltillämpande, rättsskipande, regelgenomtvingande och regelförsvarande funktioner” (s. 139). Att vara en härskande klass är att identifiera klasskaraktären hos "reglerna" i alla dessa funktioner. Reglerna är inte klassneutrala; de bidrar till att reproducera klassförhållandena i produktionssättet. I den mån regel-skapandet/tillämpningen/genomtvingandet/försvaret och rättsskipningen bidrar till bevarandet och främjandet av ett givet produktionssätt kan den dominerande klassen i det produktionssättet identifieras som den härskande klassen: "Att erövra och vara i besittning av statsmakten innebär att åstadkomma ett visst sätt att intervenera från det särskilda organ som utrustats med dessa funktioner" (s. 139-I40).

Statsmaktens klasskaraktär anges av effekterna av vad staten gör: statsmakten har en klasskaraktär i den mån som sådana effekter främjar och bevarar klassförhållandena i ett produktionssätt. Statsapparaternas

I. Denna syn på makten skiljer sig, enligt Therborn, skarpt från den dominerande ansatsen inom sociologi, som han kallar för den "subjektivistiska metoden" som "försöker att lokalisera maktens subjekt" (s. 126). Det marxistiska angreppssättet utgår däremot "inte från 'aktörens synvinkel' utan från den pågående processen av samhällelig reproduktion och transformation" (s. I26-I27). 
klasskaraktär definieras av de organisatoriska egenskaper hos staten som gör dessa effekter möjliga. Den grundläggande idén är här att "statlig makt utövas genom statsapparaten" (s. 29), men att statens förmåga att faktiskt skapa effekter som bevarar och främjar givna klassförhållanden i stor utsträckning är beroende av egenskaperna hos dessa apparater. Statsapparaten "är således ett filter som bestämmer formen för statens ekonomiska och ideologiska interventioner" (s. 146). Olika organisationsformer fyller alltså dessa filter med olika klassinnehåll, utesluter ingripanden som skulle undergräva de dominerande klassernas position och främjar ingripanden som skulle bevara och främja dessa klasser. ${ }^{2}$ Vissa former av statsapparater skulle helt enkelt vara olämpliga för utövandet av statlig makt på vissa klassers vägnar.

Boken stora innovation är att gå utöver dessa mycket generella formuleringar om statsmakt och statsapparater och försöka identifiera de specifika mekanismer i själva statsapparaterna som bidrar till klasskaraktären hos sättet att utföra dessa funktioner i olika produktionssätt. Therborn genomför denna begreppsliga uppgift genom en systematisk utforskning av variationen i statens egenskaper inom feodalism, kapitalism och socialism; den specifika karaktären hos de egenskaper hos staten som är knutna till ett givet produktionsätt följer av kontrasten till andra produktionsätt. Den resulterande analysen kombinerar ett välutvecklat analytiskt ramverk, som identifierar de relevanta strukturella elementen i statsapparaterna, med omfattande empiriska diskussioner av de historiska variationerna i statsmaskineriet under olika tider och på olika platser.

Therborn insisterar under hela sin analys på att hans föreslagna begreppsmeny över statsapparaternas klasskaraktär bör ses som provisorisk och möjlig att revidera, men betonar samtidigt att det inte är fråga om någon spekulativ filosofisk analys baserad på en rent logisk förståelse av feodalism, kapitalism och socialism. Han vill att påståendena om apparaternas klasskaraktär ska vara empiriskt grundade: kategorierna ska vara teoretiska abstraktioner från empiriska observationer av faktiskt

2. Claus Offe utvecklar på ett användbart sätt denna idé om filtermekanismer genom att föreställa sig att de genomför negativa urval med inbyggd klassbias. Negativt urval identifierar mekanismerna genom vad de utesluter: de gör vissa slags ingripanden mycket mindre sannolika än andra. Klassbiasen identifierar innehållet i det som utesluts. Se Offe I974. 
existerande samhällen snarare än rena tankeexperiment. Det låter sig lätt göras i hans undersökning av kapitalism och feodalism. Det blir mycket svårare i en undersökning av socialismen på grund av de högst skiftande uppfattningar som råder, till och med inom marxismen, om den historiska innebörden av stater som förklarade sig vara socialistiska. Therborn menar att Sovjetunionen, Kina, Kuba och andra länder som kallade sig socialistiska faktiskt, när han skrev boken, var socialistiska. Precis som kapitalistiska stater kan organiseras som liberala demokratier eller auktoritära fascistiska regimer kan, enligt Therborn, socialistiska stater vara auktoritära eller demokratiska. Även om Therborn klart förespråkar radikal demokrati ser han inte det som en nödvändig ingrediens i socialismen själv. Detta är en kontroversiell ståndpunkt, och vi ska i den andra hälften av denna artikel se att det får viktiga konsekvenser för vårt sätt att tänka om utmaningarna mot kapitalismen. Demokrati är mer centralt för socialism än för kapitalism, eftersom det utan demokrati är svårt att se vad det betyder för arbetarklassen som sådan att "utöva makt". Det är därför som jag föredrar att karakterisera Sovjetunionen och andra auktoritära kommandoekonomier som fall av ett etatistiskt produktionssätt snarare än socialism. I vilket fall som helst betraktar Therborn i Vad gör den härskande klassen när den härskar? de stater som kallade sig socialistiska i mitten av 1900-talet som lämpliga empiriska fall för byggandet av sin begreppskarta över variationer i statsapparaternas klasskaraktär.

För att genomföra denna undersökning gör Therborn upp en noggrann förteckning över de strukturella element i statsapparaterna som bestämmer inflödena till staten, omvandlingen av dessa inflöden genom statens interna praktiker och statens utflöden. Två exempel på sådana strukturella element kommer att hjälpa till att klargöra Therborns analytiska strategi: bestämningen av lämpliga uppgifter för statlig verksamhet och förvärvet av nödvändiga materiella resurser för statlig hantering. ${ }^{3}$

3. Therborn skiljer totalt mellan tolv strukturella element i statsapparaterna. Tre är knutna till inflöden (som han kallar uppgifter, personalrekrytering och energi eller förvärv av resurser); tre är knutna till omvandling (hantering av uppgifter, formande av personal, utnyttjande av resurser); fem är knutna till utföden (utrikespolitik, inrikespolitik, mellanstatlig personalhantering, inrikes personalhantering, energi); och slutligen ett element som något kryptiskt betecknas som teknologieffekter. En sammanfattande lista över dessa element återfinns på s. II4-II5. 
För det första måste varje stat, oavsett vad den gör, skilja mellan verksamheter som det är legitimt för staten att ägna sig åt och verksamheter som inte är det. Detta är i grunden problemet med relationen mellan offentligt och privat. I kapitalismen görs det en tämligen skarp åtskillnad mellan den offentliga och den privata sfären: "De frågor som den borgerliga staten sysselsätter sig med definieras ju genom den karakteristiska avgränsningen mellan privat och offentligt. Staten befattar sig enbart med det senare" (s. 6o). Även om den exakta gränsen mellan offentligt och privat ofta blir föremål för tvist och förvisso har skiftat under den kapitalistiska utvecklingens gång gäller följande:

Allmänt sett har den privata sfären sträckt sig till valet av sysselsättning och arbetsplats, valet av äktenskapspartner, ideologiska övertygelser, konsumtionsvanor och livsstilar. Den har med andra ord kommit att omfatta arbetsmarknaden, kapitalackumulationen, den borgerliga kärnfamiljen och den borgerliga "individualismens" hela fält (s. 6I).

Denna skarpa åtskillnad mellan den offentliga och den privata sfären fungerar som en klassbaserad filtermekanism för statens handlande som skyddar de centrala klassförhållandena i kapitalismen och gör det mycket svårare för staten att undergräva det privata ägandet och kapitalistklassens makt.

"Under feodalismen 'privatiseras' staten" (s. 62). Men det betyder inte, säger Therborn, att staten i feodalismen bokstavligen är kungens privata egendom. Snarare handlar det om "en sammansmältning av denna institution med de enskilda godsägarnas tillägnelse av produktionsmedlen (jorden). En av dessa växte till ställning som kung” (ibid.). Denna sammansmältning reproducerar den feodala härskande klassens makt genom att minska sannolikheten för att staten genom sina handlingar kommer att undergräva de feodala eliternas förmåga att med våld tillägna sig lämpligt överskott från bönderna.

I socialismen sker en "politisering av alla sfärer, inklusive 'privatlivet"” (s. II4). Det betyder inte att individens autonomi och val ständigt underkastas störande statlig reglering, och det är förvisso "inte liktydigt med att privatsfären sugs upp av en offentlig byråkrati" (s. 64). Det betyder snarare att den exakta gränsen för personlig autonomi blir föremål för 
offentligt övervägande. Medan filtermekanismen vid avgränsningen mellan offentligt och privat i kapitalismen skyddar det privata ägandet och främjar kapitalisternas makt bidrar politiseringen av den privata sfären i socialismen, enligt Therborn, till att säkra arbetaklassens makt.

Ett andra exempel på klassmekanismer som finns inskrivna i statsapparaterna gäller de sätt på vilka staten förvärvar de resurser som ska betala för dess handlingar. I kapitalismen sker detta huvudsakligen genom beskattning: "De medel som erfordras för allmänna ändamål skaffas genom regelbundna och obligatoriska avgifter på enskilda individer och affärsföretag" (s. 79). Offentliga budgetar kräver en förmåga att överföra inkomster från privata konton. "Under feodalismen var statsbudgeten framför allt avhängig av den kungliga domänens storlek och av den utsugningsgrad som de till den knutna bönderna underkastades" (s. 8o). På sätt och vis var kungens privata konton den direkta källan till den offentliga budgeten. Slutligen i socialismen: "Intäkterna hämtas i huvudsak från offentliga företag och beaktas direkt i den allmänna planeringsprocessen och i prissättningen av varorna” (s. 79).

Precis som i exemplet med avgränsningen mellan offentligt och privat fungerar dessa tre olika sätt att skaffa inkomster till statliga verksamheter som klassbaserade filtermekanismer till förmån för handlingar som reproducerar klassförhållandena i det kapitalistiska, det feodala respektive det socialistiska samhället. I kapitalismen, där statens inkomster är beroende av de skatter som läggs på privat ekonomisk verksamhet, tvingas staten vara uppmärksam på de verkningar som dess skatte- och utgiftspolitik får på de privata incitamenten, särskilt incitamenten för kapitalister att investera. I feodalismen tvingas staten för att få tillgång till en säker inkomstkälla bli medveten om de kungliga godsens storlek och graden av utsugning av bönderna. Och i socialismen betyder statens beroende av de överskott som skapas av offentliga företag att den pressas till att försöks stärka den klassolidaritet och klassmobilisering inom arbetaklassen som är en avgörande källa till produktivitet i en socialistisk ekonomi. 
ARKIV $\mid$ NR 8

Komplikationer och motsättningar: från produktionssätt till sambällsformation och frän strukturell form till historisk kontingens

Den analytiska ram som Therborn utvecklar för att specificera statsmaktens och statsapparaternas klasskaraktär formuleras på den abstraktionsnivå som marxister betecknar som produktionssätt. Analys på den abstraktionsnivån får en något funktionalistisk karaktär: utövandet av statlig makt reproducerar klassförhållandena i ett produktionssätt, och statsapparaterna struktureras så att dessa reproduktiva effekter underlättas. Det är nästan som att förklara statens form genom de funktionella kraven på att reproducera ett givet produktionssätt. ${ }^{4}$

Therborn förkastar bestämt ett sådant funktionalistiskt resonemang genom att betona att det inte finns någon garanti för att dessa funktionella krav faktiskt uppfylls. Faktiska stater är fulla av motsättningar, både i sin interna organisation och i sitt förhållande till det vidare samhället. Sådana motsättningar kan verka starkt störande på varje funktionell reproduktion av klassförhållandena.

Det finns tre huvudkällor till sådana motsättningar.

För det första består faktiska samhällen aldrig av ett enda produktionssätt. Staten står alltså ständigt inför problemet hur olika slags produktionsförhållanden med sina klassförhållanden står i förbindelse med varandra och interagerar inom konkreta samhällsformationer. Det öppnar möjlighet för en rad olika former av förskjutning mellan stat och ekonomi, särskilt i perioder av övergång från ett slag av ekonomisk struktur till ett annat:

Dessa välkända exempel på förskjutning mellan stat och ekonomi ger antydan om en rad komplicerade förhållanden. Det är inte bara så att flera olika klasser och produktionssätt samexisterar, utan de tränger även på många sätt in i varandra och ger upphov åt hybridformer och korsbefruktningar (s. I44).

För det andra består staten av många apparater - det handlar snarare om ett system av apparater än om "en" apparat - och det skapar risker för spänningar och förskjutningar mellan olika apparater:

4. För en konsekvent och strikt utveckling av de funktionalistiska förklaringar som kommer till uttryck i idén om bas och överbyggnad, se Cohen 1986. 
Härav följer att även om divergensen mellan statsmakten och statsapparaten begränsas av det faktum att de uttrycker samma samhälles klassförhållanden, så uppträder det vid varje särskild tidpunkt påtagliga förskjutningar mellan de båda. Möjligheterna till divergens ökas påtagligt av att det inom ett visst statssystem samexisterar flera olika apparater, i vilka olika uppsättningar av klassförhållanden kan ha utkristalliserats.

Dessa förskjutningar verkar i sista hand destabiliserande (s. 29).

För det tredje förekommer det potentiellt betydelsefulla tidsfördröjningar mellan förändringarna i ett samhälles klassförhållanden och i de organisatoriska egenskaperna hos statsapparaten. Statsapparaterna är, med Therborns ord, en "materialiserad utfällning" av klassförhållandena och "tenderar ... att manifestera dem extra fast" (s. I48). Detta är en del av skälet till att statsapparaterna kan ge ett så robust stöd åt en given samling klassförhållanden. Men det betyder också att det kan ske stora förändringar i ett samhälles klassförhållanden och klassmakt som inte omedelbart speglas i statsapparaternas klasskaraktär. De uppgifter som staten måste utföra "härstammar i grunden från den föränderliga sociala helhet i vilken den opererar" (s. 43). Denna föränderliga helhet kan rymma nya konfigurationer av klasskrafter och klassproblem. Det finns alltså möjlighet till en betydande konflikt mellan den form av klassdominans som för närvarande förkroppsligas av statsapparaterna och de uppgifter som staten åläggs att utföra:

Men en framgångsrik organisering av klassväldet inom själva statsapparaten skapar i sig nya problem för regering, administration, rättsväsen och repression problem som ifrågaä̈tter herraväldets existerande organisationsformer. Denna motsättning mellan dominans och verkställighet, vilken kan ta sig många och olika former, måste på ett eller annat sätt lösas, och den blir därför till en inre kraft för förändring av statsapparaten (s. 43).

Tillsammans visar dessa tre slag av överväganden att staten inte bör betraktas som en välfungerande maskin för reproducering av klassdominansen, utan som ett tillfälligtvis funktionellt och omstritt system. Den funktionalistiska sidan av detta argument demonstrerar hur statsapparaternas klasskaraktär sätter gränser för statens handlande så att den härskande klassen bevarar sin position i samhället; analysen av motsättningar och förskjutningar bidrar till att förklara varför dessa gränser kan bryta samman och möjligheter uppstå. 
ARKIV $\mid$ NR 8

\section{Problemet med att utmana och överskrida kapitalismen}

I mitten av sin bok förklarar Therborn varför marxistisk teori söker förstå statens klasskaraktär. Den gör det

för att upptäcka de karakteristiska samhälleliga strukturer och förhållanden som framför alla andra gynnas och skyddas av statens materiella kraft, samt för att fastställa de betingelser under vilka dessa kan ändras eller avskaffas. [...] Därmed uppstår åter frågan om hur detta klassvälde grundas och vidmakthålls, och hur det kan störtas (s. I27-I28).

Detta är en grundläggande poäng, som också speglas i en av Marx mest berömda aforismer, den elfte Feuerbachtesen: "Filosoferna har bara tolkat världen på olika sätt, det gäller att förändra den.” Målet är naturligtvis inte bara att förändra världen, utan att förändra den på ett mycket speciellt sätt: att utmana och överskrida kapitalismen genom att konstruera en alternativ ekonomisk struktur i vilken arbetaklassen kontrollerar produktionsmedlen och kapitalistklassens dominans och exploatering har avskaffats. Det är detta som grovt uppfattas som övergången från kapitalism till socialism.

En av de avgörande frågorna i teorin om hur kapitalismen överskrids är vilken roll som staten spelar för att hindra eller underlätta denna övergång. I Vad gör den härskande klassen när den härskar? formulerar Therborn problemet med övergången från kapitalism till socialism på ett tämligen traditionellt marxistiskt sätt. Hans mest explicita påstående kommer i en diskussion av förskjutningarna mellan statsmaktens (återigen: de statliga ingripandenas effekter på klassförhållandena) och statsapparaternas klasskaraktär. Therborn noterar att det historiskt har funnits många fall där statsmaktens klasskaraktär och statsapparaternas klasskaraktär inte sammanfaller. "Övergången från feodalism till kapitalism ställer just denna fråga i ett antal fall” (s. I44). Han hänvisar till England före engelska inbördeskriget och Ryssland före bolsjevikrevolutionen som fall där "statsapparaten var ännu i grunden feodal", även om det "återstod föga av feodala produktionsförhållanden" så att statsmakten inte längre främjade eller bevarade de feodala relationerna. Therborn skriver: "Faktum är att sådana förskjutningar i de flesta andra länder än Frankrike tycks ha varit regel snarare än undantag” (s. I44). Han säger sedan: 
Liknande kan även finnas i övergången från kapitalism till socialism, med den viktiga inskränkningen att en avgörande förändring $i$ statsapparaten här föregår omvandlingen av produktionsforhaallandena. NEP-perioden i Sovjetunionen, där vidmakthållandet av en socialistisk stat förenades med gynnandet av både kapitalistisk och enkel varuproduktion, är det kanske tydligaste exemplet på en sådan företeelse (s. I44, min kursivering).

Den kursiverade passagen speglar en avgörande asymmetri i traditionella marxistiska föreställningar om övergången mellan feodalism och kapitalism och övergången från kapitalism till socialism. I den förra växte de kapitalistiska relationerna fram inom feodalismen, och under en lång period karakteriseras dessa samhällen av en artikulering av båda dessa produktionssätt. Den feodala staten, särskilt i form av den absolutistiska staten, övervakar alltså en samhällsformation inom vilken feodala förhållanden gradvis undergrävs medan kapitalistiska utvidgas och fördjupas. Förstörandet av denna statsapparats feodala karaktär sker i slutet av den process under vilken feodalismen undergrävs, inte i början. I övergången från kapitalism till socialism föregår däremot "en avgörande förändring i statsapparaten ... omvandlingen av produktionsförhållandena”. Therborn diskuterar den ryska och den kubanska revolutionen som fall där "dessa revolutioner till en början [gynnade] enkel agrar varuproduktion och till och med kapitalistiska företag, samtidigt som de innebar ett mer eller mindre fullständigt krossande och en omvandling av den borgerliga statsapparaten” (s. 147). Till följd av denna framgångsrika omvandling säkrade "statsapparatens klasskaraktär åt [arbetarklassen] en avgörande styrkeposition, utifrån vilken den kunde ... ta itu med det socialistiska uppbygget" (ibid.). Kort uttryckt: i övergången från feodalism till kapitalism utvecklas kapitalistiska produktionsförhållanden och sedan omvandlas statens klasskaraktär; i övergången från kapitalism till socialism omvandlas statens klasskaraktär och sedan kan socialistiska produktionsförhållanden utvecklas jämte resterna av kapitalistiska förhållanden. ${ }^{5}$

5. Marxister hävdar ofta att produktivkrafterna inom kapitalismen gradvis får en mer och mer social karaktär, samtidigt som produktionsförhållandena fortsätter att skapa privat tillägnelse av det överskott som frambringas med hjälp av dessa produktivkrafter. Denna "motsägelse" mellan produktivkrafterna och produktionsförhållandena är ett av de villkor som krävs för att en omvandling av dessa förhållanden ska bli möjlig. Men denna omvandling sker först sedan statsmakten har erövrats och statsapparaten omvandlats. 
Detta är den traditionella marxistiska modellen. Den anammar den klassiska revolutionära visionen som betraktar erövrandet av staten och den snabba omvandlingen av dess grundläggande strukturer som ett nödvändigt villkor för utvecklingen av socialism. Detta var en inspirerande vision för antikapitalister under större delen av I900-talet, men den framstår inte längre som trovärdig för så många (om ens för någon) i dag även om de är bestämt antikapitalistiska. Det rör sig här om två grundläggande problem. För det första är det väldigt svårt att konstruera ett övertygande scenario för utvecklade kapitalistiska samhällen där antikapitalistiska krafter skulle kunna erövra statsmakten så att "ett mer eller mindre fullständigt krossande och en omvandling av den borgerliga statsapparaten" blev möjliga. Man kan föreställa sig att det under en längre period sker en demokratisering av staten genom en heterogen förändringsprocess i speciella apparater och ett skapande av nya slags kvasistatsapparater som undergrävde statens enighet; det är däremot svårt att tänka sig den plötsliga omvandling av staten som den traditionella marxistiska modellen ser som nödvändig för det "socialistiska uppbygget”. För det andra inger historiska vittnesbörd från 1900-talet inte några starkare försäkringar om, att även om det vore möjligt att krossa den borgerliga statsapparaten, resultatet skulle bli mänsklig frigörelse genom överföringen av den demokratiska makten till arbetarklassen. Om alltså en revolutionär omvälvning i den kapitalistiska staten faktiskt är ett nödvändigt villkor för socialism, antyder detta att socialism helt enkelt inte är möjligt.

Men det finns en alternativ modell för övergången från kapitalism till socialism som konstrueras kring möjligheten att det växer fram socialistiska förhållanden inom kapitalismen som undergräver dess dominans. Även om Therborn inte föreställer sig en sådan möjlighet är hans ramverk för förståelsen av de komplexa, motsägelsefulla konfigurationerna av statsmaktens och statsapparaternas klasskaraktär av samma art som denna modell av socialismen som mål och process för att komma dit. Modellen kan renodlas i fyra grundläggande argument.

I. SOCIALISM SOM EKONOMISK DEMOKRATI. Det råder ingen enighet bland antikapitalister, inte ens bland marxister, om hur socialism ska 
definieras. Spelar marknader en avgörande roll i en socialistisk ekonomi eller innebär socialism omfattande planering? Bygger socialism på statligt ägande av produktionsmedlen eller finns det en rad sociala former av ägande i en socialistisk ekonomi? Vad betyder det egentligen att arbetarklassen kontrollerar produktionsmedlen i socialismen? Är socialism det enda postkapitalistiska alternativet till kapitalism?

Ett sätt att närma sig dessa frågor är att fokusera på hur makten organiseras i ekonomiska relationer, särskilt gällande fördelningen av det sociala överskottet och kontrollen av produktionsprocessen. Detta är, skulle jag vilja påstå, den mest grundläggande gränslinjen mellan ekonomiska strukturer (eller produktionssätt i traditionell marxistisk terminologi). Hänvisning till makt öppnar naturligtvis en pandoraask av teoretiska frågor. Jag kommer att använda mig av ett medvetet nedskalat maktbegrepp: makt är förmågan att göra saker i välden, att skapa effekter. Detta är vad man kan kalla en "aktörscentrerad" föreställning om makt: människor, som handlar både individuellt och kollektivt, använder makt för att åstadkomma saker. Framför allt använder de makt för att fördela investeringar och kontrollera produktionen.

Omedelbart sett kan denna definition av makt likna det slags subjektivistiska maktbegrepp som Therborn kritiserar. Det är inte korrekt. Att jag har specificerat begreppet genom aktörer som använder makt för att åstadkomma saker i världen betyder inte att deras faktiska förmåga att göra det bestäms av aktörerna själva snarare än den struktur i vilken de är inbäddade. Kapitalister använder sin ekonomiska makt för att fördela investeringar, men de kan bara göra det på grundval av hur produktionsförhållandena ger dem dessa möjligheter. Människor utövar makt, de använder den för särskilda ändamål som delvis är deras subjektiva syften, men den makt de utövar är strukturellt bestämd och en egenskap hos de sociala relationer i vilka de agerar.

Med denna breda definition av makt kan vi alltså skilja mellan tre slag av makt som används i ekonomiska system för att fördela överskott och kontrollera produktion: ekonomisk makt, grundad på kontrollen av användningen av ekonomiska resurser; statlig makt, grundad på kontrollen av skapandet och genomdrivandet av regler i ett territorium; och vad jag kommer att kalla social makt, grundad på förmågan att mobilisera 
människor för kooperativa, frivilliga, kollektiva handlingar. ${ }^{6}$ Uttryckt som en paroll som stannar i minnet kan man få människor att göra saker genom att muta dem, tvinga dem eller övertala dem. I varje komplext ekonomiskt system finns alla tre formerna av makt, förbundna med varandra på olika sätt.

Man kan skilja ut ekonomiska strukturer på grundval av vilken av dessa former av makt som är viktigast för bestämningen av bruket av det sociala överskottet och kontrollen av produktionen. Framför allt kan kapitalismen skiljas från två postkapitalistiska ekonomiska strukturer i dessa termer: ${ }^{7}$

- Kapitalism är en ekonomisk struktur i vilken produktionsmedlen ägs privat och fördelningen och bruket av resurser för olika sociala syften sker genom utövande av ekonomisk makt. Investeringar och kontroll av produktionen är resultatet av kapitalägarnas utövande av ekonomisk makt.

- Etatism är en ekonomisk struktur i vilken produktionsmedlen ägs av staten och fördelningen och bruket av resurser för olika sociala syften sker genom utövande av statlig makt. Statstjänstemän kontrollerar investeringsprocessen och produktionen genom någon sorts statsadministrativ mekanism.

- Socialism är en ekonomisk struktur i vilken produktionsmedlen ägs socialt ${ }^{8}$ och fördelningen och bruket av resurser för olika sociala syf-

6. I viss mening är naturligtvis all makt "social”. Jag använder här uttrycket social makt i en snävare mening för att beteckna den makt som finns inbäddad i människors förmåga att göra val inom sociala interaktioner.

7. Detta är inte en fullständig teoretisk specificering av skillnaderna mellan dessa tre typer av ekonomisk struktur, utan bara deras differentiering uttryckt i maktrelationer. För en djupare diskussion, se Wright 20IO, s. III-I23.

8. Socialt ägande bör skiljas från statligt ägande. Socialt ägande av ekonomiska resurser betyder att de ägs gemensamt av alla människor i ett samhälle, och att alla följaktligen har den kollektiva rätten att besluta om fördelningen av den nettoinkomst som skapas genom bruket av dessa resurser och den kollektiva rätten att förfoga över dessa resurser. Under förutsättning att det råder djup och genomgripande demokrati blir statligt ägande ett sätt att organisera det sociala ägandet. 
ten sker genom utövande av "social makt”. Detta är i själva verket liktydigt med att definiera socialism som en genomgripande ekonomisk demokrati.

Denna definition av socialism skiljer sig från den som Therborn anammar i Vad gör den härskande klassen när den härskar? För Therborn är socialism inte en idealtypisk abstraktion; det är en teoretisk karakterisering av det slags ekonomiska system som socialister empiriskt försöker skapa: "... socialismen är det som socialisterna kämpar för att förverkliga i historien" (s. 276). Det var på denna grund som han hävdade att Sovjetunionen och Kina var empiriska exempel på socialistiska ekonomiska strukturer och socialistiska stater, även om regimerna i dessa samhällen hade många icke önskvärda egenskapen. Om socialism var den enda möjliga ekonomiska strukturen som kunde ersätta kapitalism, kunde detta vara en rimlig lösning på problemet att ge en viss empirisk grund åt diskussionen om socialism och den socialistiska staten. Men om så inte är fallet blir situationen mycket mer mångtydig, för medan socialister kan kämpa för ett alternativ till kapitalismen där arbetarna blir den dominerande klassen kan de oavsiktliga konsekvenserna av deras kamp bli något helt annat. Socialister kan kämpa för socialism men ändå skapa en auktoritär etatism och, i legitimerande syfte, kalla detta "socialism".

På grund av dessa överväganden kommer jag att använda mig av en definition av socialism som alternativ till kapitalism som inte är en abstraktion från empiriskt observerbara fall av postkapitalistiska samhällen. Men det betyder inte att detta begrepp saknar empirisk grund. Existensen av produktionsförhållanden som förkroppsligar social makt är en del av de reella strukturerna i faktiskt existerande kapitalistiska ekonomiska system. Den teoretiska extrapoleringen att dessa kan konstituera de dominerande förhållandena i en framtida ekonomi är därför inte bara en bekräftelse av normativa ideal.

För att förstå detta påstående måste vi vända oss till det andra elementet i modellen: idén att ekonomiska system är komplexa kombinationer av heterogena produktionsförhållanden. 
2. EKONOMISKA STRUKTURER SOM KOMPLEXA EKONOMISKA EKOSYSTEM. De definitioner av kapitalism, etatism och socialism som jag har föreslagit är idealtyper. Faktiska ekonomier är komplexa former av kombinationer av dessa tre typer. De är ekosystem av ekonomiska strukturer som varierar efter hur dessa olika former av makt interagerar och blandar sig. ${ }^{9}$ Att kalla en ekonomi för "kapitalistisk" är alltså en förkortning för ett mer ohanterligt uttryck som "ett ekonomiskt ekosystem som kombinerar kapitalistiska, etatistiska och socialistiska maktrelationer inom vilka de kapitalistiska dominerar". Idén om ekonomier som ekosystem dominerade av särskilda produktionsförhållanden kan användas för att beskriva vilken analysenhet som helst - företag, sektorer, regionala ekonomier, nationella ekonomier och till och med den globala ekonomin. Dessa maktrelationer genomtränger också varandra i enskilda produktionsenheter så att företag kan vara hybrider som opererar i det ekonomiska ekosystem som omger dem. Möjligheten till socialism är alltså beroende av vår förmåga att utvidga och fördjupa den socialistiska komponenten i det ekonomiska ekosystemet och försvaga de kapitalistiska och etatistiska komponenterna.

Detta sätt att förstå de ekonomiska strukturernas komplexitet känner vi igen från fallet med de kapitalistiska förhållandenas framväxt i det feodala samhället. Som Therborn skriver: "Handelskapitalet inte bara samexisterade med feodalismen inom samhällsformationen, utan inträdde även i reproduktionen av det feodala utsugningssystemet och band samman dess ekonomiska enheter" (s. 4I). Vad som är mindre bekant är att socialistiska produktionsförhållanden kan uppträda som framträdande inslag i kapitalistiska ekonomiers ekonomiska struktur. Men vad betyder det konkret? Vilka fall finns det av socialistiska produktionsförhållanden inom kapitalismen?

Här följer några exempel:

- Arbetarägda kooperativ där produktionsmedlen ägs av arbetarna och produktionen styrs genom demokratiska mekanismer.

9. Denna formulering liknar idén om "artikulering av produktionssätt", men har lite större empirisk flexibilitet eftersom några av de olika formerna i ett ekosystem kanske inte är fullt utvecklade "produktionssätt" i traditionell marxistisk mening. 
- Den sociala och solidariska ekonomi i vilken produktionen är inriktad på att tillfredsställa behov och styret organiseras på en rad olika demokratiska och kvasidemokratiska sätt.

- Markförbund där jorden avlägsnas från marknaden, dess bruk specificeras genom särskilda villkor, och förbundet självt styrs genom något slags gemenskapsbaserad styrelse.

- Kollegial kollaborativ produktion av bruksvärden, som Wikipedia och Linux.

- Statlig produktion av offentliga nyttigheter där prioriteringarna för produktionen fastställs genom robusta demokratiska processer. ${ }^{10}$

Alla dessa exempel ger på olika sätt uttryck för vissa aspekter av socialistiska produktionsförhållanden såtillvida att den sociala makten spelar en viktig roll i organiseringen av ekonomiska aktiviteter, men de får naturligtvis också ofta en hybridform i vilken även inslag av kapitalistiska förhållanden är närvarande. ${ }^{\text {II }}$ Arbetarägda kooperativ har till exempel ofta vissa anställda. Kapitalistiska företag kan till exempel betala vissa av sina anställda för att delta i kollegial kollaborativ produktion - Google ersätter vissa av sina dataingenjörer för att delta i utvecklingen av Linux, trots att detta är ett fritt mjukvarusystem. Företag i den sociala ekonomin och solidaritetsekonomin får ibland bidrag från privata stiftelser och filantroper, vars resurser kommer från kapitalistiska investeringar. Artikuleringen av kapitalistiska och socialistiska element i denna rad av komplexa sociala former är tilltrasslad, mångtydig och motsägelsefull. Ändå

IO. I mitt förslag till typologi över ekonomiska strukturer kan statens direkta tillhandahållande av offentliga nyttigheter vara ett fall av antingen etatism eller socialism eller en hybrid, beroende på i vilken utsträckning som staten själv är demokratiskt underordnad den sociala makten. Statens produktion av bruksvärden, inklusive offentliga nyttigheter, kan betraktas som ett av sätten att skapa social makt när utövandet av statlig makt självt är effektivt underordnat den sociala makten genom robusta demokratiska styrmekanismer. För en utveckling av dessa frågor, se Wright 20IO, s. I3I-I34.

II. Detaljer av dessa exempel och många andra återfinns i Wright 20Io, kapitel 7. För en mer utförlig diskussion av den komplexa hybriditeten hos dessa former, se ibid., kapitel 5 . 
utgör de alla olika sätt att organisera ekonomiska aktiviteter i vilka social makt spelar en viktig och i vissa fall dominerande roll.

3. UNDERGRÄVANDE AV KAPITALISMEN. Om man accepterar idén att kapitalistiska samhällen innehåller en rad olika icke-kapitalistiska former av ekonomisk organisering, inklusive socialistiska och protosocialistiska former, finns åtminstone möjligheten att dessa socialistiska förhållanden och praktiker kan växa och fördjupas över tid, till och med i en ekonomi där kapitalismen dominerar. Det kan ske både inom kapitalistiska företag, om de socialistiska elementen blir starkare med tiden, och inom kapitalismens bredare ekosystem, om socialistiska ekonomiska organisationer (till exempel organisationer byggda kring utövandet av social makt) intar en allt större ekonomisk plats. I det förra fallet kan det till exempel handla om en ökande roll för arbetarförsamlingar och andra former av arbetarstyre inom kapitalistiska företag, jämte ökat ägande för arbetarnas del av företagets tillgångar och deltagande i dess styrelse. I det andra fallet handlar det om utveckling och spridning av ett brett spektrum av ekonomiska organisationer som fungerar enligt ickekapitalistiska principer. Framväxten av en social ekonomi och solidaritetsekonomi i vissa delar av världen och utvecklingen av nya former av kollegial kollaborativ produktion förmedlade genom internet är exempel. Om sådana förhållanden och praktiker utvecklas tillräckligt med tiden kan alltså de kumulativa effekterna bli ett gradvis undergrävande av kapitalismens allmänna dominans. Kapitalismen skulle fortsätta att existera, men i en mer begränsad sfär av ekonomiska aktiviteter och utan att kunna lägga restriktioner på andra former av ekonomiska strukturer i det ekonomiska ekosystemet.

4. DEN KAPITALISTISKA STATEN OCH UNDERGRÄVANDET AV KAPITALISMEN. Det är en sak att observera att kapitalistiska samhällen innehåller alla möjliga icke-kapitalistiska produktionsformer, inklusive former som i viss mening har en socialistisk karaktär, och en helt annan att föreställa sig att dessa kvasisocialistiska produktionsformer kan expandera så att kapitalismens dominans undergrävs på allvar. Det avgörande problemet är alltså följande: å ena sidan är det osannolik att socialistiska pro- 
duktionsförhållanden utan stöd från staten ska kunna expandera så att kapitalismens dominans inom det ekonomiska ekosystemet undergrävs, men om å andra sidan olika former av ekonomisk-social makt på allvar hotade den kapitalistiska dominansen skulle den kapitalistiska klassen använda den kapitalistiska staten för att neutralisera detta hot. Detta är ju trots allt vad den kapitalistiska staten ska göra: reproducera de dominerande produktionsförhållandena om den ställs inför hot. Så frågan blir: Hur kan den kapitalistiska staten på en och samma gång reproducera kapitalismen och skapa förhållanden som på lång sikt undergräver kapitalismens dominans?

Om den kapitalistiska statens klasskaraktär innebar att den var en funktionellt integrerad sammanhängande maskin upptagen av att på lång sikt reproducera kapitalismen, skulle utsikterna att icke-kapitalistiska former av ekonomisk organisering undergräver den kapitalistiska dominansen verkligen vara mörka. Men Therborn hävdar i sin redogörelse för statsmakten och statsapparaterna att den kapitalistiska staten inte ska analyseras i sådana funktionalistiska termer. Mer specifikt finns det tre element $\mathrm{i}$ hans analys som ger utrymme för en mer motsättningsfylld relation mellan den kapitalistiska staten och utvecklingen av potentiellt nedbrytande alternativ till kapitalismen: heterogenitet i de olika statsapparaternas klasskaraktär; eftergifter, kompromisser och kontingent funktionalitet; och temporala inkonsekvenser i statens handlingar.

\section{Variation i statsapparaternas klasskaraktär}

Även om staten korrekt beskrivs som en "kapitalistisk stat" i kraft av klasskaraktären hos staten som helhet, som förklarades i sammanfattningen av Therborns ramverk, betonar Therborn att det inte betyder att det inte finns någon variation i specifika statsapparaters klasskaraktär:

Även om staten i en fundamental bemärkelse alltid är en enda, kan integrationsnivån hos dess apparater variera avsevärt, och det ska inte tas för givet att de har en gemensam klasskaraktär. Staten är nämligen det koncentrerade uttrycket för en högst komplicerad uppsättning klassförhållanden, vilket bryts i varierande förskjutningar mellan de olika apparaterna. Inom de gränser som sätts av statens allmänna natur är det högst troligt att de olika apparaternas klasskaraktär kommer att variera med sambandet mellan apparaternas uppgifter och strävandena hos de klasser som utgår från dessa produktionssätt (s. 36). 
Therborn klargör vidare genom att säga att "apparaten för social service, om än borgerlig, kommer att påverkas av sin nära relation till arbetarklassen” (s. 37). Det kommer sannolikt att samexistera olika statsapparater, "i vilka olika uppsättningar av klassförhållanden kan ha utkristalliserats” (s. 29). Therborn är noga med att tillägga att dessa variationer rör sig inom "de gränser som sätts av statens allmänna natur" (s. 36) och att "staten i en fundamental bemärkelse alltid är en enda" (ibid.). Han lämnar dock frågan öppen om hur vida eller snäva dessa gränser är. Framför allt öppnar apparaternas klassheterogenitet möjligheten att vissa apparater åtminstone delvis kommer att vara benägna att skydda och främja icke-kapitalistiska ekonomiska förhållanden, inte bara kapitalistiska.

Av särskild relevans vid bedömningen av variationerna i de olika statsapparaternas klasskaraktär är problemet med demokrati. Ju mer robust demokratiska ansvarighetsformerna för en viss apparat är, desto mindre rent kapitalistisk är den apparatens klasskaraktär. Till och med vanlig parlamentarisk demokrati har alltid haft en motsägelsefull klasskaraktär: det kan vara sant, som marxister i allmänhet påstår, att valdemokratins spelregler har den allmänna verkan att begränsa och tygla klasskampen om staten så att den kapitalistiska dominansen bevaras, men det är också sant att i den mån valen rymmer verklig demokratisk konkurrens för de in potentiella spänningar i de lagstiftande organens klasskaraktär. I tider av kris och folklig mobilisering kan dessa spänningar upplösa möjlighetsgränserna för nya former av statliga initiativ.

Krav på fördjupning och revitalisering av demokratin kan alltså uppfattas som krav på utspädning - inte eliminering - av statsapparaternas kapitalistiska karaktär. Det är en fråga inte bara om det vanliga statsmaskineriets demokratiska ansvar utan också om den stora variationsrikedomen i de parastatliga kommittéer och organisationer som samspelar med alla moderna stater. ${ }^{\mathrm{I2}}$ Fördjupning av demokratin är inte heller en fråga om demokratisering av bara centraliserade nationalstater utan också av lokala och regionala statsapparater. Kamp om den lokala statens demokratiska kvalitet kan vara särskilt viktig när man överväger hur

I2. För en diskussion av principerna för en demokratisk fördjupning som sträcker sig bortom de vanliga statsapparaternas gränser, se Fung \& Wright 2003. 
statliga initiativ kan vidga utrymmet för icke-kapitalistiska ekonomiska initiativ.

\section{Eftergifter, kompromisser och kontingent funktionalitet}

Medan statsmaktens klasskaraktär av Therborn definieras utifrån statens reproduktiva effekter på klassförhållandena är statens faktiska handlingar resultatet av strid, det handlar inte om en väl avvägd reaktion på funktionella krav: "Statsmakten utövas dock inte enligt någon på förhand rådande funktionalistisk harmoni utan i och genom antagonistiska klassers kamp. I denna process kan det bli nödvändigt att förlita sig till eftergifter, varigenom staten går emot kapitalackumulationens logik, fast utan att bryta den” (s. I4I). Eftergifter och kompromisser kan vara kortlivade och kastas om, eller de kan skapa mer eller mindre institutionaliserade förändringar av sociala relationer. Det öppnar också möjligheten - vilket inte diskuteras explicit av Therborn - att vissa eftergifter och kompromisser kan direkt eller indirekt skapa mer trygga platser för utveckling av icke-kapitalistiska förhållanden, inklusive förhållanden av distinkt socialistisk karaktär. Sådana möjligheter kan bli relativt varaktiga om de "kristalliseras" i särskilda statsapparater och ge dessa apparater en klasskaraktär i spänning med staten som helhet. Man kan till exempel tänka sig att vissa lokala statsapparater med ansvar för kommunutveckling eller fattigdomsbekämpning under vissa förhållanden kan knytas nära till lokala sociala rörelser som ger starkt stöd åt den sociala ekonomin, solidaritetsekonomin och arbetarkooperativ.

\section{Temporala motsättningar och förskjutningar}

Det sista elementet i Therborns analys som pekar på att det finns situationer där den kapitalistiska staten skulle tolerera och rent av uppmuntra ekonomiska praktiker med rötterna i social makt gäller de temporala motsättningarna mellan de relativt kortsiktiga reproduktiva effekterna av statliga handlingar och de långsiktiga dynamiska konsekvenserna. De reproduktiva effekterna av statliga handlingar på de dominerande produktionsförhållanden som definierar statsmaktens klasskaraktär är resultatet av handlingar som huvudsakligen reagerar på omedelbara förhållanden och utmaningar. Det var till exempel därför som den feodala 
staten underlättade handelskapitalismen även om denna på lång sikt verkade nedbrytande på de feodala förhållandena. "Handelskapitalet inte bara samexisterade med feodalismen inom samhällsformationen, utan inträdde även i reproduktionen av det feodala utsugningssystemet och band samman dess ekonomiska enheter" (s. 4I). Handelskapitalismen hjälpte den feodala härskande klassen att lösa omedelbara problem, och det var det som räknades.

På liknande sätt underlättade den kapitalistiska staten i mitten av I8oo-talet framväxten av en livskraftig offentlig sektor och offentlig reglering av kapitalismen förbunden med social demokrati. Den sociala demokratin hjälpte till med att lösa en rad problem inom kapitalismen - den hjälpte till med att reproducera kapitalismen - samtidigt som den vidgade utrymmet för olika socialistiska element i det ekonomiska ekosystemet: den partiella avvarufieringen av arbetskraften genom statens tillhandahållande av viktiga komponenter av arbetarnas materiella livsvillkor, ökningen av arbetarnas sociala makt i kapitalistiska företag och på arbetsmarknaden och demokratisk reglering av kapitalet för att hantera de värsta negativa externaliteterna av investerares och företags beteende på kapitalistiska marknader (miljöförstöring, arbetsplatsolyckor, rovlystet marknadsbeteende, marknadssvängningar och så vidare).

Det faktum att denna samling statliga handlingar bidrog till att stabilisera kapitalismen i mitten av 1900-talet tas ibland som tecken på att det inte var något icke-kapitalistiskt med dessa politiska åtgärder, och att de förvisso inte kunde betraktas som nedbrytande för kapitalismen. Det är ett misstag. Det är helt möjligt för en form av statlig intervention att få den omedelbara effekten att lösa problem för kapitalismen och till och med stärka den, och ändå sätta i rörelse en dynamik som kan undergräva kapitalismens dominans över tid. Det är just denna egenskap hos socialdemokratiska initiativ som så småningom leder till angrepp på den affirmativa staten under nyliberalismens baner när kapitalistklassen börjar inse att den expansiva affirmativa staten gradvis skapar suboptimala villkor för kapitalackumulationen. ${ }^{13}$

I3. Jag föredrar termen "affirmativ stat" (affirmative state) framför "välfärdsstat" som ett sätt att karakterisera statens expansiva roll i neutraliseringen av kapitalismens skadeverkningar, eftersom termen "välfärdsstat" ofta anses syfta på ett snävt spektrum av frågor som har med den individuella otryggheten att göra. 
Frågan för socialismen under det tjugoförsta århundradet är alltså huruvida det slaget av temporal förskjutning fortfarande är möjlig i den kapitalistiska staten. Finns det statliga interventioner som kan lösa pressande problem för kapitalismen, men som också har den potentiella långsiktiga konsekvensen att vidga det rum i vilket demokratiska, egalitära ekonomiska förhållanden kan utvecklas?

\section{Utsikter för framtiden}

Världen under 200o-talets första decennier är en helt annan än den var under den period då socialdemokratin blomstrade. Kapitalismens globalisering har gjort det mycket enklare för kapitalister att flytta investeringar till platser i världen med mindre regleringar och billig arbetskraft. Hotet om sådana kapitalrörelser jämte en rad teknologiska och demografiska förändringar har splittrat och försvagat arbetarrörelsen och gjort den mindre kapabel till motstånd och politisk mobilisering. I kombination med globaliseringen har kapitalets finansialisering lett till massiva ökningar av förmögenhets- och inkomstojämlikheterna, vilket i sin tur har ökat inflytandet för motståndarna till den socialdemokratiska staten. Kanske var decennierna under den så kallade guldåldern bara en historisk anomali, en kort period under vilken gynnsamma strukturella villkor och robust folklig mobilisering möjliggjorde den relativt egalitära, socialdemokratiska modellen för inkräktande på kapitalismens absoluta dominans. Dessförinnan var kapitalismen ett rovlystet system, och under nykapitalismen har den blivit rovlysten igen och återgått till det normala tillståndet för kapitalistiska ekonomiska ekosystem. Kanske är det i det långa loppet omöjligt att undergräva kapitalismen. Försvarare av idén om revolutionära brytningar med den kapitalistiska staten har alltid hävdat att kapitalismens dominans inte kan minskas genom reformer, och att försök att göra det var en avvikelse från uppgiften att bygga en politisk rörelse för att störta kapitalismen. Therborn anammade förvisso vid skrivandet av Vad gör den härskande klassen när den härskar? "störtandets" språk som ett sätt att tänka om en socialistisk framtid.

Men saken är kanske inte så dyster. Påståendet att globaliseringen lägger kraftiga restriktioner på staters förmåga att höja skatter, omfördela 
inkomster och främja icke-kapitalistiska former av ekonomisk verksamhet är ett politiskt effektivt påstående eftersom folk tror på det, inte därför att restriktionerna egentligen är så snäva. Inom politiken skapas möjlighetens gränser alltid delvis genom tron på dessa gränser. Nyliberalismen är en ideologi med stöd från mäktiga politiska krafter snarare än en vetenskapligt korrekt redogörelse för de faktiska gränser vi ställs inför när vi gör världen bättre. Det kan vara så att de specifika politiska åtgärder som utgjorde den socialdemokratiska menyn under guldåldern har blivit mindre effektiva och behöver omprövas, men den kapitalistiska staten förblir en motsägelsefull struktur som står inför temporalt motsägelsefyllda villkor för reproduktionen av kapitalismen.

Det finns två tendenser som ger vissa skäl till optimism om framtida möjligheter till det slags statliga initiativ som kan främja det långsiktiga undergrävandet av den kapitalistiska dominansen.

För det första innebär den globala uppvärmningen förmodligen slutet för nyliberalismen. Alldeles bortsett från frågan om hur man ska mildra den globala uppvärmningen genom en övergång till energiproduktion utan koldioxidutsläpp, kommer den nödvändiga anpassningen till den globala uppvärmningen att kräva en massiv expansion av offentliga nyttigheter. Marknaden kommer helt enkelt inte att bygga vallar till skydd för Manhattan. Storleken på de resurser som behövs för sådana statliga interventioner kan lätt komma i nivå med de totala kostnaderna för andra världskriget. Även om kapitalistiska företag kommer att dra enorm nytta av sådan produktion av offentliga nyttigheter - precis som de gynnas av militär produktion i krigstider - kommer finansieringen av sådana projekt att kräva betydande skattehöjningar och en ideologisk ansträngning att rehabilitera den affirmativa staten. Om dessa processer sker inom den kapitalistiska demokratins ramverk kan det förnyade förstärkandet av den affirmativa staten ge större utrymme för bredare och socialt orienterade statliga interventioner.

Den andra tendensen med vilken den kapitalistiska staten måste brottas under 2000-talet är de långsiktiga sysselsättningseffekterna av de teknologiska förändringar som äger rum under informationsrevolutionen. Med varje våg av teknologisk förändring följer naturligtvis spekulation om att jobb som elimineras leder till allmän marginalisering och 
permanent strukturell arbetslöshet, men under tidigare vågor skapade den ekonomiska tillväxten så småningom tillräckligt med jobb i nya sektorer för att övervinna sysselsättningstappet. De former av automation som nu tränger djupt in i tjänstesektorn, inklusive delar av professionella tjänster, gör det mycket mindre sannolikt att framtida ekonomisk tillväxt kommer att ge tillräckliga sysselsättningsmöjligheter genom den kapitalistiska marknaden. Problemets allvar förstärks ytterligare genom globaliseringen av den kapitalistiska produktionen. Dessa problem kommer bara att bli värre och kommer inte att lösas genom marknadskrafternas spontana operationer. Resultatet blir växande otrygghet och marginalisering för en betydande andel av befolkningen. Alldeles bortsett från social rättvisehänsyn kommer denna tendens sannolikt att skapa social instabilitet och kostsamma konflikter.

Dessa båda tendenser tillsammans ställer den kapitalistiska staten inför stora nya utmaningar: ett massivt ökat behov av offentliga nyttigheter för att hantera klimatförändringarna och behovet av en ny politik för att hantera den omfattande ekonomiska marginalisering som orsakas av den teknologiska förändringen. Detta är den kontext i vilken folkliga mobiliseringar och strider har vissa utsikter att skapa nya former av statlig intervention som kan stödja expansionen av mer demokratisk-egalitära former av ekonomisk verksamhet i samexistens med kapitalismen i det ekonomiska ekosystemet.

Beakta, mer specifikt, följande scenario.

Nödvändigheten att göra anpassningar till klimatförändringarna markerar slutet för nyliberalismen och dess ideologiska restriktioner. Den affirmativa staten sätter i gång med de nödvändiga väldiga arbetsprojekten och intar också en mer pådrivande roll i planeringen kring energiproduktionen för att påskynda övergången från kolbaserad energi. I det sammanhanget kommer det bredare spektrumet av roller för den affirmativa staten åter upp på den politiska dagordningen, inklusive satens ansvar för sysselsättningen och problemet med växande marginalisering och ekonomisk ojämlikhet. Men full sysselsättning genom kapitalistiska arbetsmarknader verkar alltmer osannolikt.

Ett sätt att reagera på dessa utmaningar är ovillkorlig basinkomst (OBI), ett policyförslag som har väckt allt större diskussion under 
2000-talets första decennier. ${ }^{14}$ Designen är enkel: varje lagligen bofast invånare mottar en månadsinkomst, utan några villkor, som räcker för att leva på en kulturellt respektabel, måttfull levnadsnivå. Den finansieras genom skatter och betalas ut till var och en utan hänsyn till moraliskt värde eller ekonomisk ställning. För människor med välbetalda jobb skulle skatterna naturligtvis öka mer än den OBI de erhåller så att deras nettoinkomst (lön + OBI - skatt) minskar. Men för många nettobidragsgivare skulle det ändå vara fallet att existensen av en OBI-komponent skulle upplevas som ett stabiliserande element som minskar de risker de möter på arbetsmarknaden.

OBI är en möjlig form av statlig intervention som svarar mot de svåra utmaningar som den kapitalistiska staten ställs inför när sysselsättningsmöjligheterna minskar på de kapitalistiska marknaderna. Sett ur ett för kapitalismen reproduktivt perspektiv skulle OBI åstadkomma tre saker. För det första skulle den mildra de värsta effekterna av den ojämlikhet och fattigdom som skapas genom marginaliseringen och alltså bidra till social stabilitet. För det andra skulle den ge stöd åt en annan modell av inkomstskapande arbete: självskapande av jobb för att skapa en kontrollerad inkomst för människor. OBI skulle göra en rad olika former av egensysselsättning lockande för människor även om de inte skapade tillräckligt stora inkomster för att leva på. Man kan till exempel tänka sig att fler människor skulle vara intresserade av att vara småbrukare eller trädgårdsmästare om de hade en OBI för att täcka sina basala levnadskostnader. Och för det tredje skulle OBI stabilisera konsumtionsmarknaden för kapitalistisk produktion. Som produktionssystem står kapitalistiska företags automatiserade produktion inför det inneboende problemet att inte sysselsätta tillräckligt med människor som kan köpa de saker som produceras. OBI erbjuder en vitt spridd efterfrågan på basal konsumtion. OBI kan av dessa skäl bli ett attraktivt policyalternativ för kapitalistiska eliter, särskilt när nyliberalismen uttöms som ideologi i konfrontation med en rehabiliterad affirmativ stat.

Om OBI är en attraktiv lösning på de problem som kapitalismen ställs inför, hur kan den då också bidra till undergrävandet av kapita-

I4. För en diskussion av ovillkorlig basinkomst, se Parijs I995; Ackerman, Alstott \& Parijs 2006. 
lismen? Ett centralt inslag i kapitalismen är vad Marx betecknar som arbetarnas åtskillnad från produktionsmedlen och försörjningsmedlen. Den ovillkorliga basinkomsten återförenar arbetarna med försörjningsmedlen, även om de förblir skilda från produktionsmedlen. En skattefinansierad basinkomst som tillhandhålls av staten skulle göra det möjligt för arbetarna att vägra kapitalistisk sysselsättning och i stället välja att ägna sig åt alla möjliga icke-kapitalistiska aktiviteter, inklusive dem som konstrueras genom social makt. Arbetarkooperativ skulle till exempel bli mycket mer livskraftiga om medlemmarna av kollektivet hade en grundinkomst garanterad oberoende av kooperativets kommersiella framgång. OBI skulle hjälpa till med att lösa de kreditmarknadsproblem som arbetarkooperativ ställs inför genom att göra kapitallån till kooperativ mer attraktiva för banker: sådana lån skulle plötsligt bli mindre riskfyllda eftersom inkomstströmmen från arbetskooperativet inte skull behöva täcka medlemmarnas grundläggande levnadsstandard. Ovillkorlig basinkomst vidgar alltså utrymmet för hållbara socialistiska ekonomiska relationer - byggda på social makt.

Därtill kommer att samma teknologiska utveckling som skapar marginaliseringens problem också, ironiskt nog, kan skapa ett mer robust utrymme för expansion och fördjupning av ekonomiska aktiviteter organiserade på ett mer demokratisk, egalitärt och kommunitärt sätt. Ett av de materiella produktionsvillkor som bidrar till att ge kapitalismen förankring är de växande stordriftsfördelarna i industriproduktionen: när enhetskostnaden för att producera hundratusentals enheter av något slag är mycket lägre än att bara producera några få blir det mycket svårt för småskaliga producenter att vara konkurrenskraftiga på en marknad. Kännetecknande för den kapitalistiska utvecklingens industriella era är de massiva stordriftsfördelarna. 2000-talets nya teknologier minskar i många sektorer dramatiskt stordriftsfördelarna och gör småskalig lokaliserad produktion mer livskraftig. Den mängd kapital som behövs för att köpa tillräckliga produktionsmedel för att bli konkurrenskraftig på marknaden minskar i grunden i en digital värld. Detta kommer sannolikt i sin tur att göra kooperativ och den sociala ekonomin och solidaritetsekonomin mer livskraftiga eftersom de opererar effektivare i relativt liten skala med inriktning på lokala marknader. Eller för att använda 
klassisk marxistisk terminologi: de föränderliga produktivkrafterna vidgar möjligheterna för nya produktionsförhållanden.

Andra statliga politiska åtgärder, varav många kan organiseras på lokal nivå, kan ytterligare stabilisera en dynamisk icke-kapitalistisk sektor. Ett av hindren för många former av social produktion är tillgången till fysisk mark: jord för trädgårdsskötsel och jordbruk, verkstäder för tillverkning, kontor och studior för design, rum för scenkonst och så vidare. Dessa kan tillhandahållas som offentliga förmåner av lokala myndigheter som är intresserade av att skapa en gynnsam infrastruktur för dessa mer demokratisk-egalitära former av ekonomisk verksamhet. Markförbund kan ge stöd åt urbant jordbruk. Offentligt tillhandahållna eller subventionerade makerspaces och fablabs med $3 \mathrm{D}$-skrivare och andra digitala tillverkningstekonologier kan understödja den fysiska produktionen. Utbildningsinstitutioner kan också erbjuda undervisning specifikt i frågor kring kooperativ ledning och social produktion.

Kombinationen av en OBI som gör det möjligt för människor att lämna den kapitalistiska sektorn av ekonomin, nya teknologier som underlättar utvecklingen av icke-kapitalistiska former av produktion och välvilliga lokala myndigheter som kan tillhandahålla bättre infrastruktur för dessa initiativ betyder att den sektor av ekonomin som organiseras genom social makt kan utveckla djupare rötter och expandera i aldrig förut skådade banor.

Det är viktigt att notera att allt detta skulle ske inom kapitalismen, och att dessa icke-kapitalistiska former av produktion skulle behöva hitta sätt att positivt anpassa sig till kapitalismens imperativ. Mycket input till den icke-kapitalistiska sektorn skulle produceras av kapitalistiska företag; producenter i den icke-kapitalistiska sektorn skulle köpa en del, kanske det mesta, av sin konsumtion från kapitalistiska företag; och statens produktion av offentliga nyttigheter skulle också inbegripa kontrakt med kapitalistiska företag. Även sedan denna nya konfiguration hade stabiliserats skulle staten övervaka en ekonomi i vilken kapitalismen förblev framträdande och nästan säkert dominerande. Men kapitalismens dominans skulle minska såtillvida som den lade mycket svagare restriktioner på hur människor försörjer sig och försöker skapa nya möjligheter att vidga utrymmet för social makt inom ekonomin. 
Det finns naturligtvis inget ofrånkomligt över denna utvecklingsbana. Det finns förvisso ingen garanti för att en basinkomst någonsin skulle införas, eller, om den infördes, för att en OBI skulle åtföljas av statliga initiativ för att skapa en stödjande infrastruktur för expansion av demokratiska former av ekonomisk verksamhet präglade av social makt. Det finns förvisso inte heller någon garanti för att en ovillkorlig basinkomst skulle användas av dess mottagare för att konstruera ekonomiska strukturer präglade av social makt. OBI kan faktiskt också användas för ren individuell konsumtion. Som påpekas av Philippe van Parijs omfördelar OBI "verklig frihet" åt människor och skapar goda förutsättningar för såväl lösdrivare och soffpotatisar som arbetarkooperativ och den sociala ekonomin. Hotet om parasiter som utnyttjar dem som jobbar är ett av de starka moraliska argumenten mot OBI, och sådana argument kan förvisso hindra politiska strävanden mot OBI eller åtminstone resultera $\mathrm{i}$ oönskade villkor för programmet. ${ }^{\text {Is }}$ Och vidare skulle en ovillkorlig basinkomst som var tillräckligt generös för att sätta i gång en dynamisk expansion av icke-kapitalistiska aktiviteter bli dyrbar, om än inte bortom den kapitalistiska statens fiskala kapacitet, så att om en OBI infördes skulle den sannolikt hamna på en nivå som låg under den kulturellt respektabla levnadsnivån. Det skulle också undergräva dess dynamiska effekter.

Utsikterna för att med hjälp av en ovillkorlig basinkomst och andra statliga ingrepp undergräva kapitalismen blir därför i viktiga avseenden beroende av den politiska mobiliseringen och striden kring staten. Om de i statens kapitalistiska karaktär inskrivna möjlighetsgränserna är så snäva att det blir svårt för staten att stimulera utvecklingen av sådana icke-kapitalistiska ekonomiska processer är utsikterna avlägsna. Men om, som Therborn påstår, klasskaraktären hos olika apparater kan variera en del, om den demokratiska klasskampen under vissa omständigheter kan

I5. Det finns många tänkbara villkor som kan fogas till ett förslag om basinkomst: till exempel krav på "socialt bidrag" där en person måste ge belägg för att hon ger ett visst produktivt bidrag för att få en basinkomst, eller det kan göras en behovsprövning så att bara människor under en viss inkomst- eller förmögenhetsnivå kan få en basinkomst. Vissa villkor skulle förstöra de positiva dynamiska effekterna av en basinkomst, andra skulle bara försvaga dessa effekter. 
försvaga den kapitalistiska karaktärens dominans hos vissa statsapparater, och om det är tänkbart med förskjutningar mellan nuvarande problemlösning och framtida konsekvenser, kan man tänka sig en betydande tillväxt av utrymmet för ekonomisk verksamhet byggd kring demokratiska, egalitära och kommunitära värden.

\section{Översättning: Sven-Erik Torhell}

\section{Referenser}

Ackerman, Bruce, Alstott, Anne och Parijs, Philippe van (2006) Redesigning distribution. Basic income and stakeholder grants as alternative cornerstones for a more egalitarian capitalism. London: Verso.

Cohen, G.A. (1986) Karl Marx' historieteori. Ett försvar. Lund: Arkiv förlag.

Fung, Archon och Wright, Erik Olin (2003) Deepening democracy. Innovations in empowered participatory governance. London: Verso.

Miliband, Ralph (I970) "The capitalist state - reply to Nicos Poulantzas", New Left Review nr 59.

Miliband, Ralph (1973) "Poulantzas and the capitalist state", New Left Review nr 82.

Offe, Claus (I974) "Structural problems of the capitalist state: Class rule and the political system. On the selectiveness of political institutions", i Beyme, Klaus von (red.) German political studies, vol. I. London: Sage, s. 3I-54.

Parijs, Philippe van (1995) Real freedom for all. What (if anything) can justify capitalism? Oxford: Clarendon Press.

Poulantzas, Nicos (1969) "The problem of the capitalist state", New Left Review nr 58.

Poulantzas, Nicos (1976) "The capitalist state", New Left Review nr 95.

Therborn, Göran (1980 [1978]) Vad gör den härskande klassen när den härskar? Statsapparater och statsmakt under feodalism, kapitalism och socialism. Stockholm: Zenit/Rabén \& Sjögren.

Wright, Erik Olin (2010) Envisioning real utopias. London: Verso. 

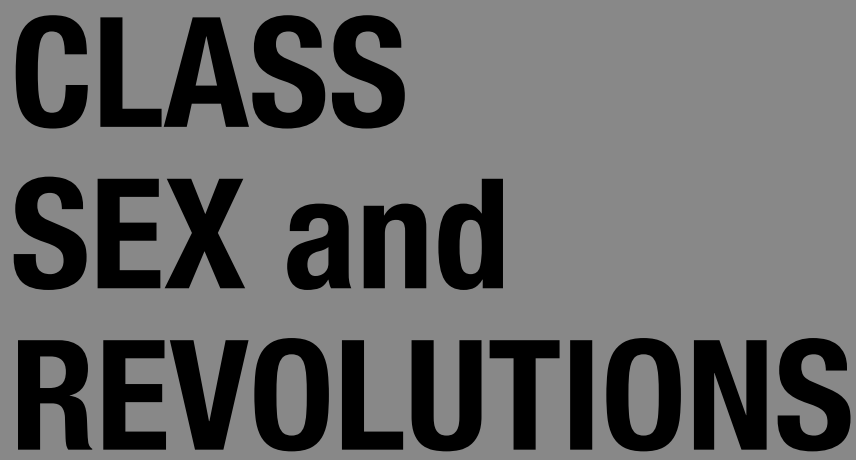

\section{Göran Therborn - a critical appraisal}

In between Science, Class and Society (1976) and The Killing Fields of Inequality (2013) Göran Therborn has consistently challenged received wisdom in politics and the social sciences. Today his work is spread across six continents, Latin America in particular, and has been translated into more than twenty languages.

This book is a critical appraisal of the themes Göran Therborn has pursued up till now, and is introduced by Robin Blackburn, for almost twenty years his editor at New Left Review. The book is edited by Gunnar Olofsson and Sven Hort.

Contributors include among others Perry Anderson, Chang Kyung-sup, Anita Göransson, Eric Hobsbawm, Habibul Haque Khondker, Åsa Cristina Laurell, Lena Lavinas, Bo Rothstein, Anders Stephanson, Immanuel Wallerstein, Karin Widerberg, Erik Olin Wright and Elisabeth Özdalga.

\section{ARKIV FÖRLAG, 436 pages}




\section{Böcker av Göran Therborn från Arkiv förlag}

Ojämlikhet dödar

2I2 sidor, Arkiv förlag 2016

Borgarklass och byråkrati i Sverige

Anteckningar om en solskenshistoria

I86 sidor, Arkiv förlag I989

Nationernas ofärd

Arbetslösheten i den internationella krisen

223 sidor, Arkiv förlag 1985

Maktens ideologi och ideologins makt

I34 sidor, Zenit 198I i distribution från Arkiv förlag

Kapitalism och rösträtt

Om den borgerliga demokratins uppkomst

67 sidor, Arkiv förlag I980

Vad gör den härskande klassen när den härskar?

Statsapparater och statsmakt under

feodalism, kapitalism och socialism

309 sidor, Zenit 1980 i distribution från Arkiv förlag

Frankfurtskolan

Till kritiken av den kritiska teorin

84 sidor, Arkiv förlag 1976

Klasser och ekonomiska system

328 sidor, Zenit 1971 i distribution från Arkiv förlag

"Böckerna går att beställa i bokhandeln och från www.arkiv.nu“ 